\title{
MENANAMKAN SIKAP TOLERANSI PADA MAHASISWA UNTUK MENINGKATKAN PERSATUAN DAN KESATUAN MAHASISWA
}

\author{
Adriani Marince Un \\ IIK Strada Indonesia \\ rinceadriana30.@gmail.com
}

\begin{abstract}
ABSTRAK
Toleransi merupakan sikap saling menghargai dan menghormati antar kelompok maupun antarindividual,di mana kita sebagai manusia harus tahu etika dan sopan santun yang sudah di tanamkan dalam diri kita masing-masing.Dalam hal ini kita sebagai manusia harus bisa menanamkan sikap bertoleransi terhadap sesame kita agar terciptanya rasa keharmonisan dan terciptanya kenyamanan.Untuk menanamkan sikap toleransi sangat penting di sebuah universitas, agar membantu mahasiswa untuk menyatukan segala perbedaan yang ada dan menjadikan sesuatu yang bermakna bagi setiap individu,dan berbagai bentuk keberagaman serta menjadikan itu semua sebagai bentuk keindahan tersendiri yang ada di negara kita Indonesia.
\end{abstract}

\section{LATAR BELAKANG}

Indonesia adalah negara yang terdiri dari berbagai kelompok etnis,budaya,suku,dan agama,sehingga Indonesia secara sederhana dapat disebut sebagai masyarakat multicultural.Dalam hal ini kita sebagai masyarakat Indonesia harus bisa beradaptasi dengan lingkungan sekitar,baik dalam keluarga,sekolah,maupun masyarakat.

Semboyan Bhineka Tunggal Ika merupakan pernyataan yang mengakui realitas Indonesia majemuk(bhineka)namun selalu mencita-citakan terwujudnya kesatuan.Sebagai negara Indonesia kita harus memiliki pandangan dan tingkah laku yang baik dalam kehidupan seharihari baik di masyarakat maupun di kampus.Maka dari itu diharapkan agar mahasiswa dapat menciptakan sesuatu yang berbeda,dimana kita sebagai mahasiswa dapat bersosialisasi,serta beradaptasi dan bertoleransi tanpa harus memandang suku,agama,budaya serta perbedaan Bahasa maupun warna kulit.Demi menciptakan keharmonisan dan kenyamanan supaya tidak saling menyalakan satu sama lain tetap menjaga nama baik kampus.Multikul tural di latar belakangi mahasiswa yang berasal dari berbagai suku,agama,budaya dan ras.Maka dari itu,agar dapat tetap menciptakan keharmonisan dan persatuan mahasiswa wajib menerapkan sikap toleransi agar tetap terciptanya kenyamanan di dalam kampus.

Kita percaya bahwa bhineka tunggal ika merupakan alat pemersatu bangsa dimana disini kita 
berasal dari daerah yang berbeda-beda,tetapi kita tetap bertumpah darah dan bertanah air yang sama.

\section{KASUS/MASALAH}

Bagaimana peran mahasiswa dalam membangun sikap toleransi agar terciptanya keharmonisan dan kenyamanan di dalam kampus?

\section{TINJAUAN PUSTAKA}

Faktor pendukung timbulnya rasa toleransi pada lingkungan perguruan tinggi diantaranya,rasa senasib pada diri mahasiswa untuk dapat menerima satu sama lain agar terciptanya keharmonisan dan kenyamanan di dalam kampus.Pada hakikatnya manusia tidak dapat hidup sendiri dan membutuhkan orang lain,interaksi yang terjalin juga turut di pengaruhi tingginya toleransi oleh mahasiswa.Perkembangan nilai toleransi juga turut di dukung oleh perguruan tinggi dengan cara memberi ruang sikap saling menghormati,menghargai dan saling terbuka.

Peran mahasiswa dalam membangun sikap toleransi agar terciptanya keharmonisan dan kenyamanan di lingkungan kampus dengan cara :terhindar dari perpecahan,meningkatkan rasa persaudaraan,mempersatukan perbedaan,meningkatkan rasa nasionalisme dan memudahkan mencapai mufakat.Sikap toleransi harus diterapkan dimana saja kita berada.Tantangan untuk terus menjaga kesatuan dan persatuan Indonesia adalah kewajiban kita sebagai generasi muda,generasi penerus bangsa untuk memperkuat dan mempertahankan sikap saling menghormati dan mejadikan toleransi sebagai sebuah kesadaran bahwa setiap masyarakat meskipun dengan latar belakang suku,agama,dan ras yang berbeda kita adalah sama dan tetap satu,Indonesia.

\section{PEMBAHASAN}

Di dalam memaknai toleransi ini terdapat dua penafsiran tentang konsep tersebut.Pertama penafsiran negative yang menyatakan bahwa toleransi itu cukup mensyaratkan adanya sikap membiarkan dan tidak menyakiti orang atau kelompok lain baik yang berbeda maupun sama.Sedangkan yang kedua adalah penafsiran positif yaitu menyatakan bahwa toleransi tidak hanya sekedar seperti pertama(penafsiran negatif),tetapi harus adanya bantuan dan dukungan terhadap keberadaan orang lain atau kelompok lain.Multikultural merupakan keragaman atau perbedaan terhadap suatu kebudayaan dengan kebudayaan yang lain.

Kampus dikenal sebagai kampus multicultural yang berarti banyak/beragam budaya.Mahasiswa berasal dari daerah yang berbeda serta kota yang berbeda pula,makanya 
di perlukan agar sesama mahasiswa harus memiliki rasa solidaritas serta bersosialisasi dan mampu beradaptasi agar bisa menanamkan sikap/sifat toleransi.

Berdasarkan Pembahasan di atas dapat di pahami bahwa motivasi dalam meningkatkan toleransi di antara sesama mahasiswa yaitu di mana kita sebagai mahasiswa harus saling menghormati serta tidak membeda-bedakan ras,suku,agama,dan budaya.Dalam hal ini kita minta agar kita tetap bersosialisasi dan tetap menjaga perilaku kita sebagai pelajar yang beretika,dan sebagai anak muda (mahasiswa) tanamkan jiwa yang semangat dan menjadi generasi penerus bangsa Indonesia.

Penanaman toleransi disini juga guna untuk membantu membantu mahasiswa menerapkan sikap toleransi mereka dalam membangun hubungan yang baik supaya menciptakan keharmonisan dalam hidup bermasyarakat,dan menghadirkan rasa kekeluargaan .Perilaku toleransi juga dapat menanamkan persatuan dan kesatuan di sebuah negara yang beragam dan di ciptakan salah satunya dengan perilaku masyarakat yang menghormati keberagaman tersebut.Sikap toleransi berarti menanam diri,bersikap sabar,membiarkan orang berpendapat lain,dan berhenti lapang terhadap orang-orang yang memiliki pendapat yang berbeda beda.Toleransi sejati didasarkan sikap hormat kepada martabat manusia,hati Nurani dan keyakinan,serta keiklasan sesama,baik agama,suku,golongan,maupun budaya.Dalam hal ini kita sebagai anak muda bangsa Indonesia harus mempunyai jiwa yang semangat dalam membangun mengenai keanekaragaman yang ada dinegeri kita dengan cara menghindar rasa egoisme/fanatisme.Maka,dari itu kita Bersama-sama turun kelapangan untuk bekerja sama demi membangun rasa pendamaian serta menciptakan rasa persatuan dan kesatuan yakni bangsa Indonesia.

\section{KESIMPULAN}

Penanaman toleransi terhadap mahasiswa bermultikultural merupakan salah satu sikap yang harus di kembangkan oleh setiap individu.Penanaman toleransi keberagaman dilakukan melalui pengkondisian lingkungan di kampus yang terdiri dari keberagaman latar belakang mahasiswa baik secara sosial maupun budaya.Strategi selanjutnya melalui pemodelan atau contoh sikap dari educator dan warga kampus yang berkaitan dengan nilai nilai keberagaman seperti toleransi,tolong menolong,dan menghargai sesama.Untuk upaya penanaman toleransi terhadap sesama dalam rangka untuk mencapai kepentingan Bersama agar mahasiswa saling bertoleransi antara sesamanya serta menjadi manusia yang beriman kepada Tuhan yang maha esa,berilmu,berakhlak mulia, serta kreatif dan menjadi warga negara yang bertanggung jawab. 


\section{DAFTAR PUSTAKA}

Daiman, Y. M., \& Iswahyudi, D. (2019, December). Penanaman Toleransi Pada Mahasiswa PPKn Dari Berbagai Budaya. In Prosiding Seminar Nasional Fakultas Ilmu Pendidikan (Vol. 3, pp. 242-247). Khasanah, N. (2017). IMPLEMENTASI NILAI TOLERANSI TERHADAP MAHASISWA LINTAS KEYAKINAN PADA PERGURUAN TINGGI DI YOGYKARTA. Prodi PPKn Universitas PGRI Yogyakarta. 